УДК 634.8:631.524.86/544:632.4

DOI https://doi.org/10.32848/agrar.innov.2021.5.26

\title{
ВПЛИВ РЕЖИМІВ КРАПЛИННОГО ЗРОШЕННЯ НА ПРОДУКТИВНІСТЬ ВИНОГРАДУ ЗА ВИРОЩУВАННЯ В УМОВАХ ПІВДНЯ УКРАЇНИ
}

\author{
ВОЖЕГОВ С.Г. - доктор сільськогосподарських наук, \\ старший науковий співробітник \\ https://orcid.org/0000-0003-0877-2593 \\ Інститут рису НАAН \\ Ощипок О.С. - здобувач \\ https://orcid.org/0000-0003-3994-5602 \\ Інститут зрошуваного землеробства НАAН \\ КОкОВІХІH C.В. - доктор сільськогосподарських наук, профессор \\ https://orcid.org/0000-0002-1687-6889 \\ Інститут зрошуваного землеробства НААН \\ ДРОБІтькО А.В. - доктор сільськогосподарських наук, доцент, \\ https://orcid.org/0000-0002-6492-4558 \\ гирля л.М. - кандидат хімічних наук \\ https://orcid.org/0000-0002-8964-4253 \\ Миколаївський національний аграрний університет \\ KEPIMOB А.Н. - кандидат сільськогосподарських наук, доцент \\ https://orcid.org/0000-0001-8549-1547 \\ КАЗАНОК О.О. - кандидат сільськогосподарських наук, доцент \\ https://orcid.org/0000-0002-6817-4985 \\ Херсонський державний аграрно-економічний університет
}

Постановка проблеми. Зміни клімату, що проявляються у суттєвому зростанні температурного режиму на фоні дефіциту природної вологозабезпеченості обумовлюють необхідність змін наукових підходів до формування технологій сільськогосподарських культур, у тому числі й винограду. Оптимізація технологій вирощування саджанців винограду нових високопродуктивних сортів, а також розробка і впровадження інноваційних агрозаходів для отримання якісного посадкового матеріалу за використання краплинного зрошення має велике значення в сучасному виноградарстві України [1-3].

Аналіз останніх досліджень і публікацій. Штучне зволоження створю сприятливі умови не тільки для рослин винограду, але також сприяє зростанню й підвищенню шкодочинності шкідливих організмів, у першу чергу збудників хвороб. До того ж агротехніка вирощування виноградних саджанців та товарних насаджень на поливних землях сприяє створенню іншого фрітоклімату в зоні формування пагонів і листя, порівняно з фрітокліматом у кроні куща. Це не дозволяє науково обґрунтувати раціональну технологію вирощування саджанців та промислових насаджень за різних режимів краплинного зрошення та захисту виноградних саджанців від збудників хвороб з урахуванням сортової специфрічності сучасного сортименту культури, особливо при використанні біопрепаратів, що $\epsilon$ актуальною науковою і практичною проблемою [4]. Ця технологія передбачає використання біопрепаратів в двох перших або в двох останніх обприскуваннях. Однак ця технологія розроблена з урахуванням максимального збереження врожаю на плодоносних насадженнях. Важливе наукове й практичне значення має наукове обґрунтування захисту виноградних саджанців від збудників хвороб, з урахуванням сортової специфічності сучасного сортименту винограду, є актуальною проблемою [5].
Матеріал і методи досліджень. Метою досліджень було визначити ефективність застосування краплинного зрошення за вирощування промислового винограду в умовах Півдня України.

Дослідження проводили в умовах Правобережної нижньодніпровської зони виноградарства України на базі Агрофрірми «Білозерський» (Херсонська область, Білозерський район, с. Дніпровське) впродовж 2011-2013 рр. Зрошення - крапельне: поливна трубка 16 мм, крапельниці встановлені через 15 см, витрата води 4,8 л/год. на 1 м, профріль зволоження 0,3 м. Польові досліди закладали згідно «Методичних вказівок по державних випробуваннях фрунгіцидів, антибіотиків і протруйників насіння сільськогосподарських культур» [6], «Методичних рекомендацій по агротехнічним дослідженням у виноградарстві України» [7].

Результати досліджень. Спостереженнями на насадженнях винограду сорту Шардоне встановлено, що кількість вічок найменшого значення - 33,4 шт. набула у посушливому 2012 р. (табл. 1). Досліджуваний показник збільшився на 11,1\%, до 37,1 у 2013 р. зі сприятливими гідротермічними умовами та застосуванні біологічно оптимального поливного режиму. В середньому за роки проведення досліджень, при порівнянні варіантів краплинного зрошення, проявилася перевага біологічно оптимального режиму з максимальною кількістю вічок - 35,5 шт. У варіанті з ресурсоощадним поливним режимом краплинного зрошення відбулося зменшення даного показника на 1,9\% - до 34,8 шт.

За неполивних умов всього сформувалось пагонів на кущі, в середньому, 33,7 шт. У варіанті з ресурсоощадним поливним режимом відзначено дуже слабке збільшення цього показника на 0,5\%, до 33,9 шт.

У варіанті з і біологічно оптимальним режимом краплинного зрошення одержали загальну кількість пагонів на кущі таку саме, як і на неполивному контролі - 33,7 шт. 
Доведена суттєва різниця між кількістю плодоносних пагонів, яка значною мірою зростала в роки зі сприятливими погодними умовами та при проведенні вегетаційних поливів краплинним зрошенням.

У контрольному варіанті цей показник продуктивності винограду склав, у середньому за роки проведення досліджень, 20,9 шт. У варіанті з ресурсоощадним режимом зрошення він підвищився до 22,5 шт., або на $7,1 \%$, а за біологічно оптимального таке зростання склало $11,6 \%$.

Таблиця 1 - Розвиток і плодоносність пагонів винограду сорту Шардоне під впливом краплинного зрошення в роки проведення досліджень

\begin{tabular}{|c|c|c|c|c|c|c|}
\hline \multirow{3}{*}{$\begin{array}{c}\text { Краплинне } \\
\text { зрошення }\end{array}$} & \multirow{3}{*}{$\begin{array}{c}\text { Роки } \\
\text { дослі- } \\
\text { джень }\end{array}$} & \multirow{3}{*}{$\begin{array}{l}\text { Вічок } \\
\text { на } \\
\text { кущ,, } \\
\text { шт. }\end{array}$} & \multicolumn{3}{|c|}{$\begin{array}{c}\text { Розвинулось паго- } \\
\text { нів на кущі }\end{array}$} & \multirow{3}{*}{$\begin{array}{c}\text { Число } \\
\text { суцвіть } \\
\text { на } \\
\text { кущ, } \\
\text { шт. }\end{array}$} \\
\hline & & & \multirow{2}{*}{$\begin{array}{c}\text { всього, } \\
\text { шт. }\end{array}$} & \multicolumn{2}{|c|}{$\begin{array}{l}\text { В т.ч. пло- } \\
\text { доносних }\end{array}$} & \\
\hline & & & & шт. & $\%$ & \\
\hline \multirow{3}{*}{$\begin{array}{r}\text { Без поливу } \\
\text { (контроль) }\end{array}$} & 2011 & 35,6 & 34,7 & 22,9 & 65,6 & 33,0 \\
\hline & 2012 & 33,4 & 31,9 & 18,7 & 58,6 & 24,8 \\
\hline & 2013 & 34,2 & 34,3 & 21,1 & 61,5 & 30,4 \\
\hline \multirow{3}{*}{$\begin{array}{c}\text { Ресурсо- } \\
\text { ощадний } \\
\text { режим } \\
\text { зрошення }\end{array}$} & 2011 & 35,1 & 35,7 & 24,5 & 68,6 & 36,8 \\
\hline & 2012 & 33,7 & 31,8 & 20,4 & 64,2 & 27,7 \\
\hline & 2013 & 35,8 & 34,2 & 22,6 & 66,1 & 33,3 \\
\hline \multirow{3}{*}{$\begin{array}{c}\text { Біологічно } \\
\text { оптималь- } \\
\text { ний режим } \\
\text { зрошення }\end{array}$} & 2011 & 35,6 & 34,9 & 24,4 & 69,9 & 39,4 \\
\hline & 2012 & 33,9 & 32,0 & 22,1 & 69,1 & 33,6 \\
\hline & 2013 & 37,1 & 2 & 24,3 & 71,1 & 35,3 \\
\hline \multicolumn{2}{|l|}{$\mathrm{HIP}_{05}$} & 0,98 & 0,74 & 0,56 & 1,51 & 1,12 \\
\hline
\end{tabular}

Досліджувані режими краплинного зрошення істотно позначилися на формуванні площі листкової поверхні на 1 кущі винограду (табл. 2). За неполивних умов у 2012 р. цей показник зменшився до 4,95 м², а у варіанті з біологічно оптимальним поливним режимом зафіксовано його зростання до $11,48 \mathrm{~m}^{2}$.

У середньому за роки досліджень листкова площа 1 куща склала за неполивних умов 6,32 м². Застосування краплинного зрошення за ресурсоощадної технологією сприяло зростанню цього показника до 7,79 або на $18,9 \%$. Біологічно оптимальний режим краплинного зрошення дозволив сформувати найбільшу в досліді площу асиміляційної поверхні 1 куща винограду на рівні 9,56 м², що більше за ресурсоощадний режим на 22,5\%, а за контроль - на $33,8 \%$.

Листкова площа у перерахунку на 1 га насаджень винограду також істотно залежала від умов вологозабезпечення. Доведено, що мінімальний показник асиміляційної площі досліджуваної культури на рівні 13,2 тис. м²/га виявився у посушливому 2012 р. у неполивному контрольному варіанті. Цей показник збільшився

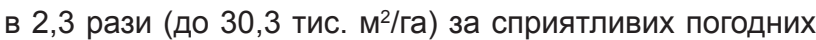
умов 2011 р. та проведенні поливів за біологічно оптимальним режимом краплинного зрошення.

\section{Таблиця 2 - Розвиток листової поверхні}

та її продуктивність сорту Шардоне під впливом краплинного зрошення в роки проведення досліджень

\begin{tabular}{|c|c|c|c|c|}
\hline \multirow[b]{2}{*}{$\begin{array}{c}\text { Краплинне } \\
\text { зрошення }\end{array}$} & \multirow{2}{*}{$\begin{array}{c}\text { Роки } \\
\text { дослі- } \\
\text { джень }\end{array}$} & \multicolumn{2}{|c|}{$\begin{array}{c}\text { Площа листової } \\
\text { поверхні }\end{array}$} & \multirow{2}{*}{\begin{tabular}{|c|} 
Умовна \\
врожай- \\
ність ягід (г) \\
в перерахунку \\
на 1 м² листко $^{2}$ вої площі
\end{tabular}} \\
\hline & & $\begin{array}{c}\text { на } 1 \\
\text { кущі, } \text { м² }^{2}\end{array}$ & $\begin{array}{c}\text { на } \\
1 \text { га, } \\
\text { тис. } \text { м }^{2}\end{array}$ & \\
\hline \multirow{3}{*}{$\begin{array}{l}\text { Без поливу } \\
\text { (контроль) }\end{array}$} & 2011 & 6,67 & 17,7 & 418 \\
\hline & 2012 & 4,95 & 13,2 & 379 \\
\hline & 2013 & 7,34 & 19,5 & 379 \\
\hline \multirow{3}{*}{$\begin{array}{c}\text { Ресурсо- } \\
\text { ощадний } \\
\text { режим } \\
\text { зрошення }\end{array}$} & 2011 & 9,24 & 24,6 & 370 \\
\hline & 2012 & 5,94 & 15,8 & 367 \\
\hline & 2013 & 8,21 & 21,7 & 410 \\
\hline \multirow{3}{*}{$\begin{array}{c}\text { Біологічно } \\
\text { оптимальний } \\
\text { режим } \\
\text { зрошення }\end{array}$} & 2011 & 11,48 & 30,3 & 310 \\
\hline & 2012 & 7,57 & 20,1 & 433 \\
\hline & 2013 & 9,62 & 25,6 & 371 \\
\hline \multicolumn{2}{|l|}{$\mathrm{HIP}_{05}$} & 0,30 & 0,95 & 8,37 \\
\hline
\end{tabular}

Показник умовної врожайності ягід винограду в перерахунку на $1 \mathrm{~m}^{2}$ листкової площі свідчить про перевагу використання ресурсоощадного режиму краплинного зрошення. Так, на цьому варіанті даний показник склав $436 r / \mathrm{m}^{2}$, що більше біологічно оптимальний режим на $7,6 \%$, а порівняно з неполивним контролем - на 1,6\%.

Встановлено, що параметри водного режиму грунту досліджуваної культури суттєво коливались за варіантами поливних режимів та залежно від особливостей

Таблиця 3 - Евапотранспірація винограду, сумарне водоспоживання та його коефіцієнт залежно від режиму зрошення в роки проведення досліджень

\begin{tabular}{|c|c|c|c|c|c|c|c|}
\hline \multirow[b]{2}{*}{$\begin{array}{c}\text { Краплинне } \\
\text { зрошення }\end{array}$} & \multirow[b]{2}{*}{$\begin{array}{c}\text { Роки } \\
\text { досліджень }\end{array}$} & \multirow[b]{2}{*}{$\begin{array}{c}\text { Евапотранс- } \\
\text { пірація, } \\
\text { мм/добу }\end{array}$} & \multicolumn{4}{|c|}{ Баланс водоспоживання, м³/га } & \multirow[b]{2}{*}{$\begin{array}{c}\text { Коефіцієнт } \\
\text { водоспоживання } \\
\text { м³/т }\end{array}$} \\
\hline & & & $\begin{array}{c}\text { ґрунтова } \\
\text { волога }\end{array}$ & опади & поливи & $\begin{array}{c}\text { сумарне } \\
\text { водоспожи- } \\
\text { вання }\end{array}$ & \\
\hline \multirow{3}{*}{$\begin{array}{l}\text { Без поливу } \\
\text { (контроль) }\end{array}$} & 2011 & 0,43 & 327 & 1158 & - & 1485 & 201 \\
\hline & 2012 & 0,48 & 589 & 695 & - & 1284 & 257 \\
\hline & 2013 & 0,41 & 375 & 1287 & - & 1662 & 225 \\
\hline \multirow{3}{*}{$\begin{array}{c}\text { Ресурсо- ощад- } \\
\text { ний режим } \\
\text { зрошення }\end{array}$} & 2011 & 0,48 & 397 & 1158 & 802 & 2357 & 259 \\
\hline & 2012 & 0,46 & 647 & 695 & 1132 & 2474 & 427 \\
\hline & 2013 & 0,48 & 458 & 1287 & 794 & 2539 & 285 \\
\hline \multirow{3}{*}{$\begin{array}{c}\text { Біологічно опти- } \\
\text { мальний режим } \\
\text { зрошення }\end{array}$} & 2011 & 0,48 & 435 & 1158 & 930 & 2523 & 268 \\
\hline & 2012 & 0,46 & 602 & 695 & 1324 & 2621 & 301 \\
\hline & 2013 & 0,49 & 515 & 1287 & 922 & 2724 & 287 \\
\hline
\end{tabular}


погодних умов у роки проведення досліджень (табл. 3). Евапотранспірація у контрольному варіанті сягнула найвищого рівня 0,48 мм/добу у посушливому 2012 році, а за сприятливих погодних умов у 2011 і 2013 роки відбулося ії зменшення до 0,41-0,43 мм/добу. У зрошуваних варіантах проявилася тенденція зростання цього показника у варіанті з біологічно оптимальним режимом зрошення до 0,49 мм/добу в 2013 році.

Ґрунтова волога меншою мірою використовувалась виноградом за неполивних умов, де цей показник складав 327-589 м³/га. Він підвищився на 9,7-48,5\% (до $647 \mathrm{~m}^{3} /$ га) за ресурсоощадного режиму зрошення та високих температур повітря у 2012 році.

Максимальне сумарне водоспоживання в межах 2621-2724 м³/га сформувалось за біологічно оптимального режиму зрошення у 2012 і 2013 роках, а мінімальний рівень даного показника - 1284 м³/га проявився за неполивних умов 2012 року.

Коефіцієнт водоспоживання мав тенденцію зниження до $201 \mathrm{~m} 3 / \mathrm{T}$ у неполивному контролі за сприятливих погодних умов 2011 року та підвищення цього показника у 2,1 рази, до $427 \mathrm{~m} 3 / \mathrm{T}$ - за ресурсоощадного режиму зрошення за посухи 2012 року.

За результатами узагальнення експериментальних даних встановлено, що мінімальна кількість грон (20,9 шт.) сфрормувалась на неполивному варіанті за посушливої погоди у 2012 р. (табл. 4).

Цей показник збільшився в 1,4 рази (до 29,2 шт.) у варіанті з біологічно оптимальним режимом краплинного зрошення за сприятливих умов 2011 р. У середньому по досліджуваних режимах краплинного зрошення, найменша кількість грон на кущі на рівні 25,1 шт. виявилася на неполивному варіанті. Застосування ресурсоощадного режиму краплинного зрошення обумовило підвищення цього показника, в середньому, до 26,6 шт. або на $5,5 \%$.

Маса грона була найменшою - на рівні 81-86 г у неполивному варіанті в 2011 та 2012 рр. Цей біометричний показник зріс до 115 г у середньовологому 2013 р. при застосуванні біологічно оптимального режиму краплинного зрошення. В середньому по фактору, зафріксовано суттєве зростання маси грона на 15,4-27,1\% з 89 гу контрольному неполивному варіанті до 102-110 г - у варіантах з ресурсоощадним та біологічно оптимальним режимом краплинного зрошення.
Урожайність ягід з куща винограду також змінювалось у широкому діапазоні залежно від режимів краплинного зрошення та погодних умов у роки проведення досліджень. За сприятливої метеорологічної ситуації у 2011 і 2013 рр. цей показник продуктивності досліджуваної культури склав у неполивному варіанті 2,872,93 кг/кущ.

У перерахунку на 1 га насаджень досліджуваної культури врожайність ягід віддзеркалювала тенденції, що були зафріксовані стосовно врожайності з 1 куща. Так, найменша продуктивність рослин на рівні 6,6 т/га була на у неполивному варіанті. Використання краплинного зрошення за ресурсоощадної та біологічно оптимальною схемою забезпечило підвищення врожайності на 16,8-28,3\% - до 7,9-9,2 т/га. Максимальну врожайність в досліді на рівні 9,5 т/га одержали за біологічно оптимального режиму зрошення у 2013 р., а мінімальну - 5,0 т/га, у неполивному контрольному варіанті.

Дисперсійна обробка одержаних врожайних даних винограду довів про вагому роль зрошення при вирощуванні досліджуваної культури з істотними коливаннями питомої ваги окремих чинників (рис. 1).

Встановлено, що максимальний вплив на врожайність винограду мали режими краплинного зрошення, оскільки їх частка впливу була найвищою й складала 59,8\%. Також високе значення мали - їх питома вага дорівнює 27,5\%. Взаємодія досліджуваних чинників дорівнює 7,5\%. На дію неврахованих агротехнологічних фракторів припадає 5,2\% мінливості результативних ознак.

Висновки. Досліджувані режими краплинного зрошення істотно позначилися на ростових процесах і біометричних показниках. За неполивних умов у 2012 р. листкова площі зменшилась до 4,95 м², а у варіанті з біологічно оптимальним поливним режимом зафріксовано його зростання до 11,48 м². Доведено, що евапотранспірація у контрольному варіанті сягнула найвищого рівня 0,48 мм/добу у посушливому 2012 році, а за сприятливих погодних умов у 2011 і 2013 роки відбулося ії̈ зменшення до 0,41-0,43 мм/добу. Максимальне сумарне водоспоживання в межах 2621-2724 м³/га ссрормувалось за біологічно оптимального режиму зрошення у 2012 і 2013 роках, а мінімальний рівень даного показника - $1284 \mathrm{~m}^{3} /$ га проявився за неполивних умов 2012 року. Коефіцієнт водоспоживання мав тенденцію зниження до $201 \mathrm{~m}^{3} / \mathrm{T}$ у неполивному контролі. Урожайність ягід з куща вино-

Таблиця 4 - Біометричні показники грон та врожайність ягід винограду сорту Шардоне залежно від варіантів краплинного зрошення

\begin{tabular}{|c|c|c|c|c|c|}
\hline \multirow{2}{*}{ Краплинне зрошення } & \multirow{2}{*}{ Роки досліджень } & \multirow{2}{*}{$\begin{array}{c}\text { Кількість } \\
\text { грон на кущ, шт. }\end{array}$} & \multirow{2}{*}{$\begin{array}{c}\text { Маса грона, } \\
\text { г }\end{array}$} & \multicolumn{2}{|c|}{ Урожайність } \\
\hline & & & & з 1 куща, кг & 1 га, т \\
\hline \multirow{3}{*}{$\begin{array}{l}\text { Без поливу } \\
\text { (контроль) }\end{array}$} & 2011 & 29,0 & 86 & 2,87 & 7,4 \\
\hline & 2012 & 20,9 & 81 & 1,93 & 5,0 \\
\hline & 2013 & 25,5 & 100 & 2,93 & 7,4 \\
\hline \multirow{3}{*}{$\begin{array}{c}\text { Ресурсо- ощадний режим } \\
\text { зрошення }\end{array}$} & 2011 & 28,7 & 106 & 3,48 & 9,1 \\
\hline & 2012 & 23,8 & 92 & 2,26 & 5,8 \\
\hline & 2013 & 27,3 & 109 & 3,40 & 8,9 \\
\hline \multirow{3}{*}{$\begin{array}{c}\text { Біологічно оптимальний } \\
\text { режим зрошення }\end{array}$} & 2011 & 29,2 & 108 & 3,62 & 9,4 \\
\hline & 2012 & 25,8 & 107 & 3,33 & 8,7 \\
\hline & 2013 & 27,8 & 115 & 3,65 & 9,5 \\
\hline \multicolumn{2}{|l|}{$\mathrm{HIP}_{05}$} & 0,72 & 2,61 & 0,10 & 0,25 \\
\hline
\end{tabular}




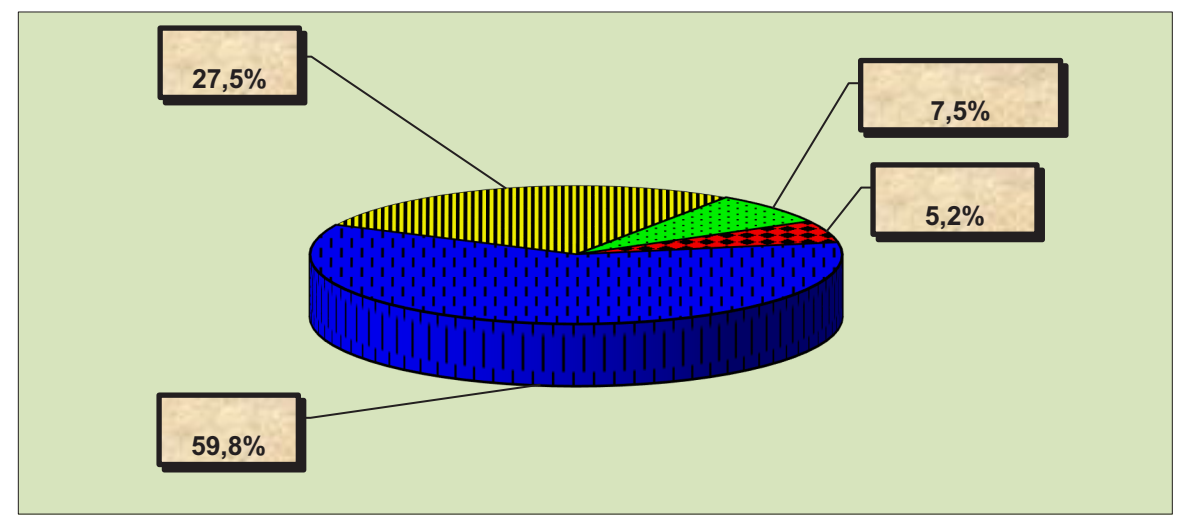

Рис. 1. Мінливість результативних ознак впливу режимів краплинного зрошення (фактор А) та погодних умов у роки проведення досліджень (фактор B), \%

граду також змінювалось у широкому діапазоні залежно від режимів краплинного зрошення та погодних умов у роки проведення досліджень. За сприятливої метеорологічної ситуації у 2011 і 2013 рр. цей показник продуктивності досліджуваної культури склав у неполивному варіанті 2,87-2,93 кг/кущ. Найменша врожайність у перерахунку на 1 га була на рівні 6,6 т у неполивному варіанті. Використання краплинного зрошення за ресурсоощадної та біологічно оптимальною схемою забезпечило підвищення врожайності на 16,8-28,3\% - до 7,9-9,2 т/ га. Максимальну врожайність в досліді на рівні 9,5 т/га одержали за біологічно оптимального режиму зрошення у 2013 р. Встановлено, що максимальний вплив на врожайність винограду мали режими краплинного зрошення, оскільки їх частка впливу була найвищою й складала $59,8 \%$. Також високе значення мали погодні умови в роки проведення досліджень - їх питома вага дорівнює 27,5\%. Взаємодія досліджуваних чинників склала 7,5\%.

\section{СПИСОК ВИКОРИСТАНОЇ ЛІТЕРАТУРИ:}

1. Якушина Н. А. Устойчивость сортов Подарок Магарача и Первенец Магарача к болезням и вредителям. Виноградарство и виноделие СССР. 1986. № 4. C. 25.

2. Доля П. В., Якушина Н. А. Продуктивность насаждений сортов Подарок Магарача и Первенец Магарача в Днепровской Левобережной степной зоне виноградарства Украины. «Магарач». Виноградарство и виноделие. 2011. № 2. С. 11-14.

3. Чичинадзе Ж. А., Якушина Н. А., Скориков А. С., Странишевская Е. П. Вредители, болезни и сорняки на виноградниках. Киев : Аграрная наука, 1995. 305 с.

4. Якушина Н. А. Индуцированный иммунитет и новые системные фунгициды в защите винограда от болезней грибной этиологии : дисс... д-ра с.-х. наук. Киев, 1996. 316 c.

5. Алейникова Н. В., Мирзаев И. Б., Андреев В. В. Экологизация системы защиты столовых сортов винограда от милдью в условиях Крыма. «Магарач». Виноградарство и виноделие. 2014. № 4. С. 19-20.

6. Методические указания по государственным испытаниям фуунгицидов, антибиотиков и протра- вителей семян сельскохозяйственных культур / под. ред. Новожилова К. В. Москва : Колос, 1985. 89 с.

7. Методические рекомендации по агротехническим исследованиям в виноградарстве Украины / под. ред. А. М. Авидзба. Ялта : Институт винограда и вина «Магарач», 2004. 264 с.

\section{REFERENCES:}

1. Dolya, P.V., \& Yakushina, N.A. (2011). Produktivnost nasazhdeniy sortov Podarok Magaracha i Pervenets Magaracha $v$ Dneprovskoy Levoberezhnoy stepnoy zone vinogradarstva Ukrainy [Productivity of plantings of varieties gift of magarach and the firstborn of magarach in the Dnieper left-bank steppe viticulture zone of Ukraine]. Vinogradarstvo $i$ vinodeliye USSR Viticulture and winemaking of the USSR, 2, 11-14 [in Russian].

2. Yakushina, N.A. (1986). Ustoychivost' sortov Podarok Magaracha i Pervenets Magaracha k boleznyam i vreditelyam [Resistance of varieties gift of magarach and the firstborn of magarach to diseases and pests]. "Maharach». Vynohradarstvo y vynodelye- "Magarach". Viticulture and winemaking, 4, 25 [in Russian].

3. Chichinadze, Z.A., Yakushina, N.A., Skorikov, A.S., \& Stranishevskaya, Ye.P. (1996). Vrediteli, bolezni $i$ sornyaki na vinogradnikakh [Pests, diseases and weeds in the vineyards]. Kiyev: Agrarnaya nauka [in Russian].

4. Yakushina, N.A. (1996). Indutsirovannyy immunitet i novyye sistemnyye fungitsidy $v$ zashchite vinograda ot bolezney gribnoy etiologii [Induced immunity and new systemic fungicides in the protection of grapes from diseases of fungal etiology]. Kyev [in Russian].

5. Aleynikova, N.V., Mirzayev, I.B. \& Andreyev, V.V. (2014). Ekologizatsiya sistemy zashchity stolovykh sortov vinograda ot mild'yu v usloviyakh Kryma [Ecologization of the system for protecting table grape varieties from mildew in the crimea]. "Maharach». Vynohradarstvo $y$ vynodelye - "Magarach". Viticulture and winemaking, 4, 19-20 [in Russian].

6. Novozhilova, K.V. (1985). Metodicheskiye ukazaniya po gosudarstvennym ispytaniyam fungitsidov, antibiotikov i protraviteley semyan selskokhozyaystvennykh kultur [Guidelines for state testing of fungicides, antibiotics and seed dressers for crops]. Moscow: Kolos [in Russian]. 
7. Avidzba, A.M. (2004). Metodicheskiye rekomendatsii po agrotekhnicheskim issledovaniyam $v$ vinogradarstve Ukrainy [Methodological recommendations for agricultural research in the viticulture of Ukraine]. Yalta: Institut vinograda i vina «Magarach» [in Russian].

Вожегов С.Г., Ощипок О.С., Коковіхін С.В., Дробітько А.В., Гирля Л.М., Керімов А.Н., Казанок О.О. Вплив режимів краплинного зрошення на продуктивність винограду за вирощування в умовах Півдня України

Мета. Визначити ефективність застосування краплинного зрошення за вирощування промислового винограду в умовах Півдня України. Методи. Дослідження проводили в умовах Правобережної нижньодніпровської зони виноградарства України - на базі Агрофрірми «Білозерський» (Херсонська область, Білозерський район, с. Дніпровське) впродовж 2011-2013 рр. Польові досліди закладали згідно загальновизнаних методик дослідної справи. Результати. Досліджувані режими краплинного зрошення істотно позначилися на ростових процесах і біометричних показниках. Урожайність ягід з куща винограду також змінювалось у широкому діапазоні залежно від режимів краплинного зрошення та погодних умов у роки проведення досліджень. За сприятливої метеорологічної ситуації у 2011 і 2013 рр. цей показник продуктивності досліджуваної культури склав у неполивному варіанті 2,87-2,93 кг/ кущ. Найменша врожайність у перерахунку на 1 га була на рівні 6,6 т у неполивному варіанті. Використання краплинного зрошення за ресурсоощадної та біологічно оптимальною схемою забезпечило підвищення врожайності на 16,8-28,3\% - до 7,9-9,2 т/га. Висновки. За неполивних умов у 2012 р. листкова площі зменши-

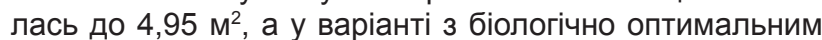
поливним режимом зафріксовано його зростання до

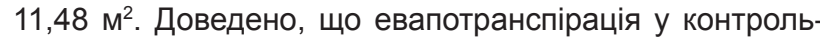
ному варіанті сягнула найвищого рівня 0,48 мм/добу у посушливому 2012 році, а за сприятливих погодних умов у 2011 і 2013 роки відбулося ії̈ зменшення до 0,410,43 мм/добу. Максимальне сумарне водоспоживання в межах 2621-2724 м³/га сформувалось за біологічно оптимального режиму зрошення у 2012 і 2013 роках, а мінімальний рівень даного показника - 1284 м³/га проявився за неполивних умов 2012 року. Коефіцієнт водоспоживання мав тенденцію зниження до 201 м³ $^{3}$ т у неполивному контролі. Максимальну врожайність в досліді на рівні 9,5 т/га одержали за біологічно оптимального режиму зрошення у 2013 р. Встановлено, що максимальний вплив на врожайність винограду мали режими краплинного зрошення, оскільки їх частка впливу була найвищою й складала 59,8\%. Також високе значення мали погодні умови в роки проведення досліджень - їх питома вага дорівнює 27,5\%. Взаємодія досліджуваних чинників склала $7,5 \%$.
Ключові слова: виноград, краплинне зрошення, продуктивність рослин, площа листя, водоспоживання, врожайність, мінливість результативних ознак.

Vozhegov S.G., Osgchipok O.S., Kokovikhin S.V., Drobitko A.V., Girlya L.M., Kerimov A.N., Kazanok O.O. Influence of drip irrigation regimes on productivity of grapes for cultivation in the conditions of the South of Ukraine

Goal. To determine the effectiveness of drip irrigation for growing industrial grapes in the South of Ukraine. Methods. The research was conducted in the conditions of the Right Bank Lower Dnieper Zone of Viticulture of Ukraine - on the basis of Agrofirm "Belozersky" (Kherson Region, Belozersky District, Dniprovske village) during 2011-2013. Field experiments were established according to generally accepted research methods. Results. The studied modes of drip irrigation significantly affected the growth processes and biometric indicators. The yield of berries from the grape bush also varied in a wide range depending on the drip irrigation regimes and weather conditions during the years of research. With a favorable meteorological situation in 2011 and 2013, this indicator of productivity of the studied crop in the non-irrigated version was $2.87-2.93 \mathrm{~kg} / \mathrm{bush}$. The lowest yield per 1 ha was at the level of 6.6 tons in the non-irrigated version. The use of drip irrigation according to the resource-saving and biologically optimal scheme provided an increase in yield by $16.8-28.3 \%$ - up to 7.9 9.2 t/ha. Conclusions. Under non-irrigated conditions in 2012, the leaf area decreased to $4.95 \mathrm{~m}^{2}$, and in the version with a biologically optimal irrigation regime, its growth was recorded to $11.48 \mathrm{~m}^{2}$. It is proved that evapotranspiration in the control variant reached the highest level of $0.48 \mathrm{~mm} /$ day in the dry year of 2012, and under favorable weather conditions in 2011 and 2013 it decreased to $0.41-0.43 \mathrm{~mm} /$ day. The maximum total water consumption in the range of $2621-2724 \mathrm{~m}^{3} / \mathrm{ha}$ was formed under the biologically optimal irrigation regime in 2012 and 2013 , and the minimum level of this indicator $-1284 \mathrm{~m}^{3} / \mathrm{ha}$ was manifested under non-irrigated conditions in 2012. The water consumption coefficient tended to decrease to $201 \mathrm{~m}^{3} / \mathrm{t}$ in non-irrigated control. The maximum yield in the experiment at the level of $9.5 \mathrm{t} / \mathrm{ha}$ was obtained under the biologically optimal irrigation regime in 2013. It was found that the maximum impact on the yield of grapes had drip irrigation regimes, as their share was the highest and was $59.8 \%$. Also of great importance were the weather conditions during the years of research - their share is $27.5 \%$. The interaction of the studied factors was $7.5 \%$.

Key words: grapes, drip irrigation, plant productivity, leaf area, water consumption, yield, variability of performance traits. 